\title{
Utilization of Landsat Satellite Imagery to Observe Environmental Change at Sinabung Mountain Area
}

\author{
Togi Tampubolon ${ }^{1}$, Rita Juliani ${ }^{2}$, Juniar Hutahaean ${ }^{3}$ \\ topartam@gmail.com \\ Department of Physics, State University of Medan, Indonesia ${ }^{1,2,3}$
}

\begin{abstract}
Ten years long eruption at Mt. Sinabung 2009 to 2018 generated a diverse surface environment, which is located in Sumatra Island, Indonesia. In fact, most of the eruption event probably being aware to vegetation changes and temperature changes during those eruptions shown in that period. Therefore, there was abundant data of satellite imagery to support the observation of stunning eruption one of the satellite imagery is Landsat 8 OLI. Field survey is also as evidence for fluctuated of volcanic activity during the Mt. Sinabung eruption by using position tracking, scenery taking, and temperature monitoring. Scope of observation is limited around $5 \mathrm{~km}$ and processed by using ArcGIS 10.3 and ENVI 4.7. In particular, results indicated that the intensity of Mt. Sinabung eruption increased every year, since 2009. According to temperature and vegetation information provided by Landsat 8 OLI shows an increase in temperature (by land surface temperature index or LST) simultaneously with a decrease in vegetation index (by Normalized Difference Vegetation Index or NDVI). In accordance with that information, this results confirm Mt. Sinabung erupted influences the environment stability.
\end{abstract}

Keywords: Thermometer, GPS, Environmental change, Landsat 8 OLI, NDVI, LST.

\section{Introduction}

In North Sumatra there are several volcanoes, both active and inactive, one of which is Sinabung Mountain which is located in Karo District with an altitude of 2,475 amsl (above mean sea level) with currently active status (Febrianty, 2017). This mountain has not been active for a long time, since the last magmatic eruption in 1600. Society in North Sumatra was shocked by its active return on August 2010 where phreatic eruptions occurred (Sutawidjaja, 2013). The condition of temperature and lava distribution in the research area that has not been identified will cause there is an expansion possibility of damage area that can harm the local residents (Safitri, 2014). The Observation of the surrounding eruptions effects cannot be done manually, because of the danger of heat, toxic gases and larvae. How to observe the negative impacts Eruptions around $5 \mathrm{~km}$ from the mountain becomes the problem in this study.

Research to observe the negative impacts around this mountain can be done with remote sensing (RS). Technically RS can identify: lava deposits after eruption, temperature, NDVI and also can identify natural damage (water, soil, plants). Remote sensing techniques also can be used to monitor the negative effects of eruption. Remote sensing is the science and art of obtaining information about an object, area, or phenomenon through analysis of data obtained with a device without direct contact with objects, regions, or phenomena being studied and followed by processing, analysis, and interpretation of the data (Howard, 1996). How remote sensing can observe the environment, which is remote sensing consists of 3 main components 
namely sensed objects, sensors to record objects and electro-magnetic waves reflected or emitted by the earth's surface.

Interaction when this component produces remote sensing data which then through the interpretation process can know the type of object area or phenomena that exist (Lillesand \& Kiefer, 1979). This study uses Landsat TM satellite data which has the characteristics: $30 \mathrm{~m}$ spatial resolution for NDVI, 1 Scene image Landsat has wide $190 \mathrm{~km}$ x $195 \mathrm{~km}$, 16-day temporal resolution (ESRI, (2001). Photograph images can theoretically capture the colours and gradations indefinitely beyond digital media that can be received by computer monitors and other output equipment (Prasetyo,2011) whereas thermal bands are very useful for detecting differences in the earth's surface temperature with a 100 meter spatial resolution (Mulyanta, 2006)and knowing the damaged area level, and temperature due to eruptions and information on areas that are vulnerable to eruption disasters that are categorized as alert and safe in disaster mitigation (Thoha, 2008). This study focused on identification: NDVI, LST and land damage. The results of this study can be used by the government and local communities to mitigate natural disasters.

\section{Research Methodology}

This research methodology consists of location and time observation, tools and materials, and data analysis.

\subsection{Location and Time Observation}

Geographically, Karo Regency is located between $2^{\circ} 50$ '- $3^{\circ} 19^{\prime}$ North Latitude and $97^{\circ} 55^{\prime}-$ $98^{\circ} 38^{\prime}$ East Longitude with an area of $2,127.25 \mathrm{~km} 2$ or 2.97 percent of the area of North Sumatra Province. The study location is geographically between $3008^{\prime} 45.61$ north latitude and $98020^{\prime} 12.54$ east longitudes with $5 \mathrm{~km}$ of the central area of Sinabung Mountain.

\subsection{Tools and Materials}

This section includes:

\subsubsection{Tools}

For the field survey, we use GPS (Global Position System), DNS Garmin, Microsoft Office 2007, Digital Cameras, Alcohol Thermometers. For data analysis, our results supported by ArcGIS 10.3 and ENVI 4.7.

\subsubsection{Materials}

Research materials are spatial satellite imagery data in 2009, 2011, 2014,2015,2016,2017 and 2018, attribute data of North Sumatra Earth Map and Administration Map of Tanah Karo District (shp) (Mulyanta, 2006).

\subsection{Data Analysis}

This section will explain the research processing.

1. Firstly, we do some radiometric correction at all band of Landsat 8 OLI using an equation

2. We do mask between the data with administration map to collocate the area observation. 
3. Next, we calculate the parameter such as Normalized Difference Vegetation Index (NDVI) and Land Surface Temperature (LST).

$$
\begin{gathered}
\text { NDVI }=\frac{\text { BandNIR }- \text { Band } \operatorname{Re} d}{\text { BndNIR }+ \text { Band } \operatorname{Re} d} \\
T I=\left(\frac{K_{2}}{\operatorname{In}\left(\frac{K_{1}}{L_{\lambda}}+1\right)}\right)
\end{gathered}
$$

Where,

NDVI is normalized difference vegetation index

$\mathrm{TI}$ is temperature index

$\mathrm{K} 1$ is first constants (774.89)

$\mathrm{K} 2$ is second constants (1321.08)

4. Then, we classify and count the moderate area and risk area.

\section{Result and Discussion}

Landsat 8 OLI image data processing requires field survey data as reference points for processing the data. On the other hand, band satellite image data is 1 to 11 USGS sources, to display surface images where on Landsat $8 \mathrm{OLI}$, true colour from RGB results to 4,3,2 where $\mathrm{R}=$ Band 4 (Red), $\mathrm{G}=$ Band 3 (Green) and $\mathrm{B}=$ Band 2 (Blue). On Landsat 8 OLI Digital Number that is 16 bits, $216=65,356$ minimum price $=0$ (Black) and maximum price $=65,355$ (White). Figure 1 and Figure 2 shows the distribution of Mt. Sinabung eruption in 2016 and 2018. Thisfigures include those image of Landsat 8 OLI to indicates the area that has been damaged by the mountains, with the NDVI value and temperature in the area. This section includes:

\subsection{NDVI results}

Map of NDVI values calculation in the Sinabung Mountain area from 2009 to 2018 can be seen in Figure 2.a, 2.b, 2.c and 2.d below. 


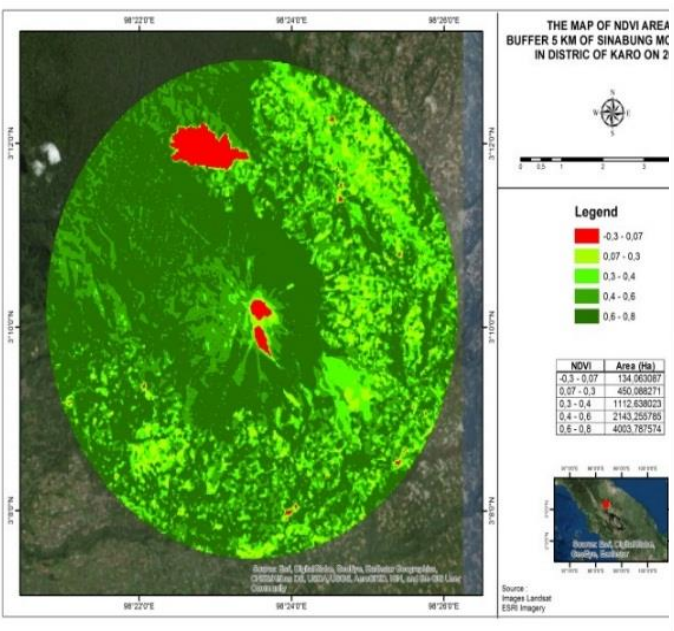

(a)

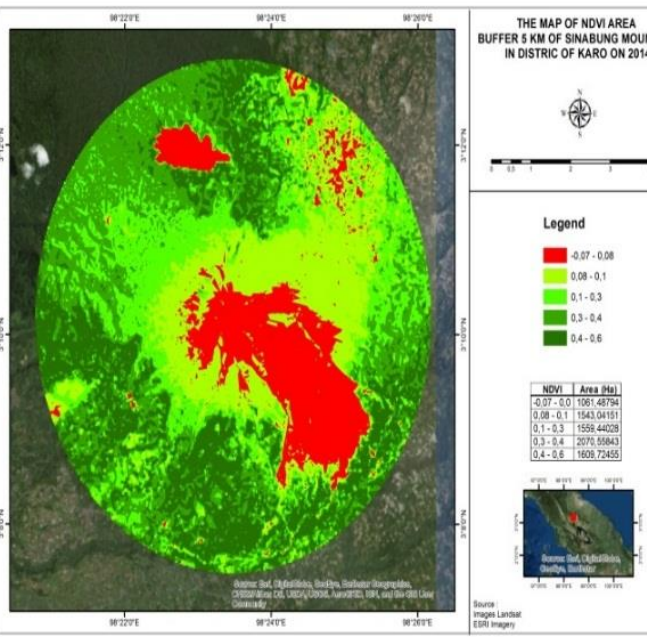

(b)

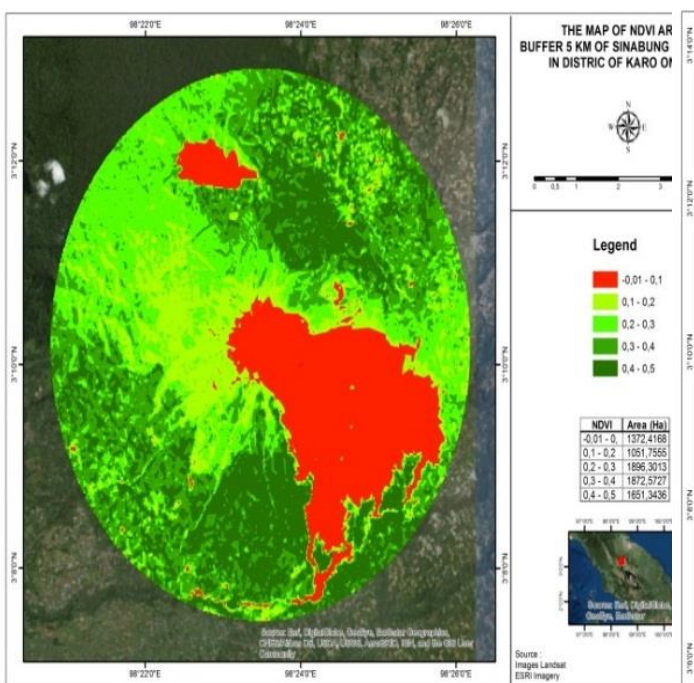

(c)

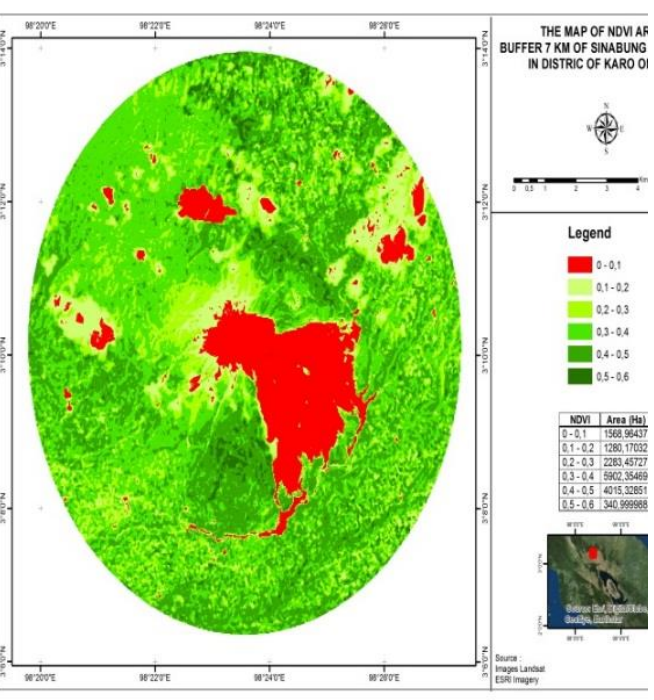

(d)

Fig 1: Mean value of Normalized Difference Vegetation Index (NDVI) at $5 \mathrm{~km}$ of Mt. Sinabung in (a). 2009; (b). 2014; (c) 2016; and (d) 2018. Erupted area shown in legend from dark green to the light red.

The figure above shows that NDVI values had a dramatically decline and it is obviously seen in Figure.1a in 2009 it still looks high at 0.8 emu with little deforested land caused by local and national tourists who climbed before Sinabung Mountain eruption, then it had a significant decrease from 2014.2016 and 2018 with a value of $0.6 \mathrm{emu}, 0.5 \mathrm{emu}$ and $0.60 \mathrm{emu}$. It can be seen in Figure.1.b, 1.c and 1.d. It shows the activity of Mt. Sinabung strongly influences the changes in the surrounding of NDVI, mountain activities are increasingly high by removing eruptions and bursts of hot clouds towards the south of the mountain slope which caused the diminishing green land. Thos information shown on 
Table 1. NDVI value from Landsat 8 OLI 2009 to 2018

\begin{tabular}{lll}
\hline No. & Year & NDVI Value \\
\hline 1 & 2009 & $0.6-0.8 \mathrm{emu}$ \\
2 & $\mathbf{2 0 1 4}$ & $\mathbf{0 . 4}-\mathbf{0 . 6} \mathbf{~ e m u}$ \\
3 & $\mathbf{2 0 1 6}$ & $\mathbf{0 . 4}-\mathbf{0 . 5}$ emu \\
4 & $\mathbf{2 0 1 8}$ & $\mathbf{0 . 5}-\mathbf{0 . 6} \mathbf{~ e m u}$
\end{tabular}

\subsection{LST results}

TI maps in Mt. Sinabung from 2009-2018 can be seen in Figure 2.

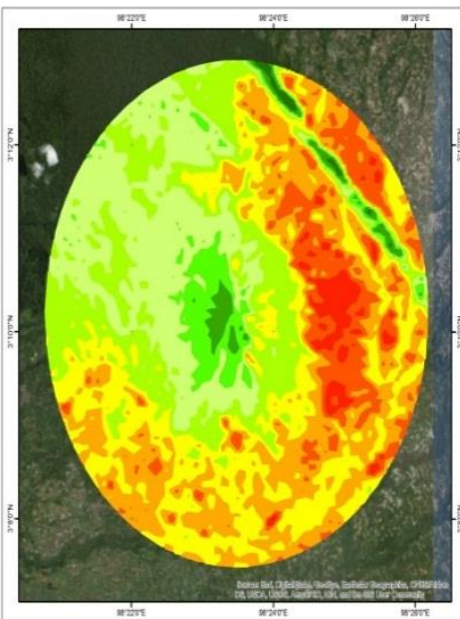

(a)

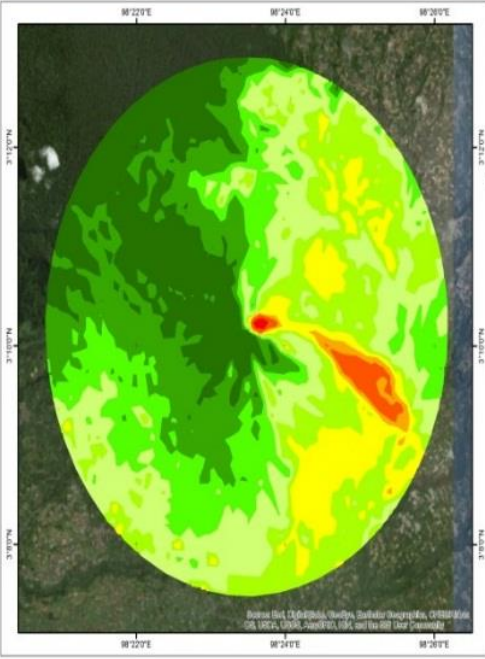

(c)

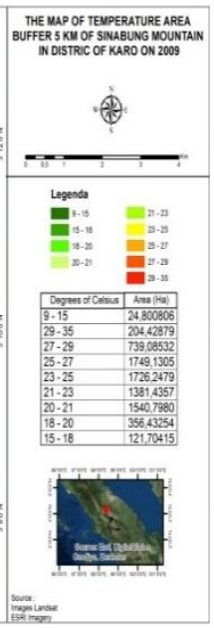

insine

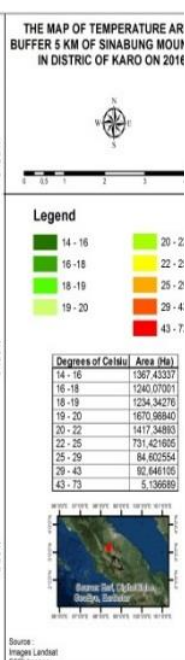

then

(LST) at $5 \mathrm{~km}$ of Mt. Sinabung in (a) 2009

(b)
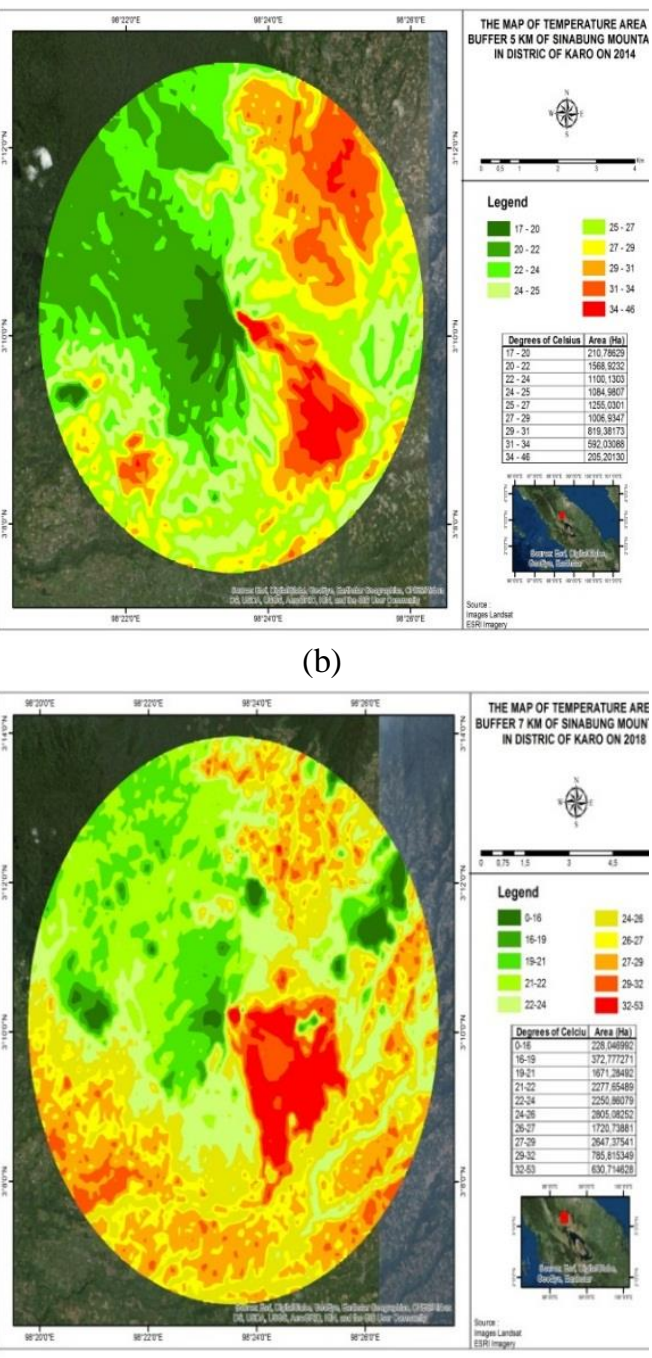

Fig 2: Mean value of thermal index (LST) at $5 \mathrm{~km}$ of Mt. Sinabung in (a). 2009; (b). 2014; (c) 2016; and (d) 2018. Erupted area shown in legend from dark green to the light red. 
The temperature map above can be concluded that temperature in 2009 was still low at the top of Mt. Sinabungbecause there was no eruption.In Figure 2.a. showspeak of increasing valuecauses of eruption of Mt. Sinabung in 2014, 2016, and 2018. It can be seen in red colour which has a temperature value of $24-26^{\circ} \mathrm{C}$ and the red colour temperature of $32-53^{\circ} \mathrm{C}$ at these temperatureshas exceeded the normal limits of humans and plants for life and it is not feasible to live and grow crops. The temperature in 2018 looks very significant compared to the previous year. It can beseen in Table 2 below.

Table 2. LST value from Landsat 8 OLI 2009 to 2018

\begin{tabular}{lll}
\hline No. & Year & NDVI Value \\
\hline 1 & 2009 & $15-18{ }^{\circ} \mathrm{C}$ \\
2 & $\mathbf{2 0 1 4}$ & $34-46^{\circ} \mathrm{C}$ \\
3 & $\mathbf{2 0 1 6}$ & $\mathbf{4 3}-\mathbf{7 3}^{\circ} \mathbf{C}$ \\
4 & $\mathbf{2 0 1 8}$ & $\mathbf{3 2}-\mathbf{5 3}^{\circ} \mathbf{C}$
\end{tabular}

\subsection{Sinabung Mountain Environmental Changes}

Before Mt. Sinabung eruption, it was still relatively green around the peak of Sinabung so there was no land damage.

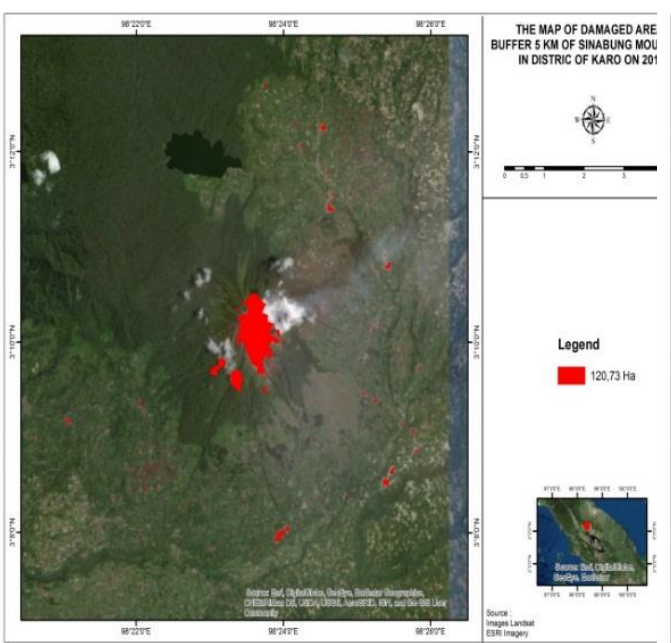

(a)

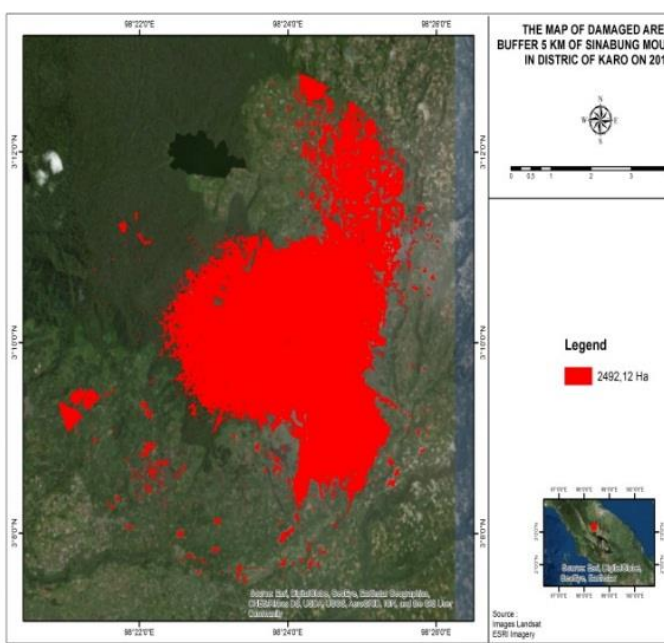

(b) 


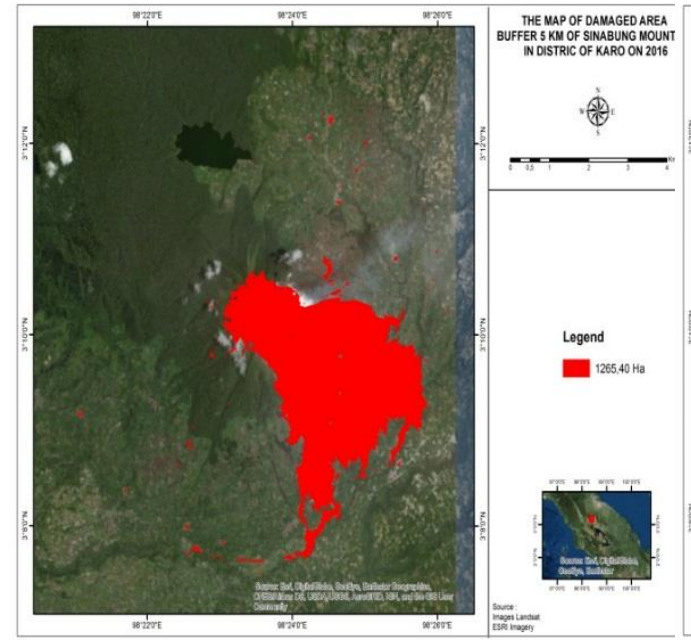

(c)

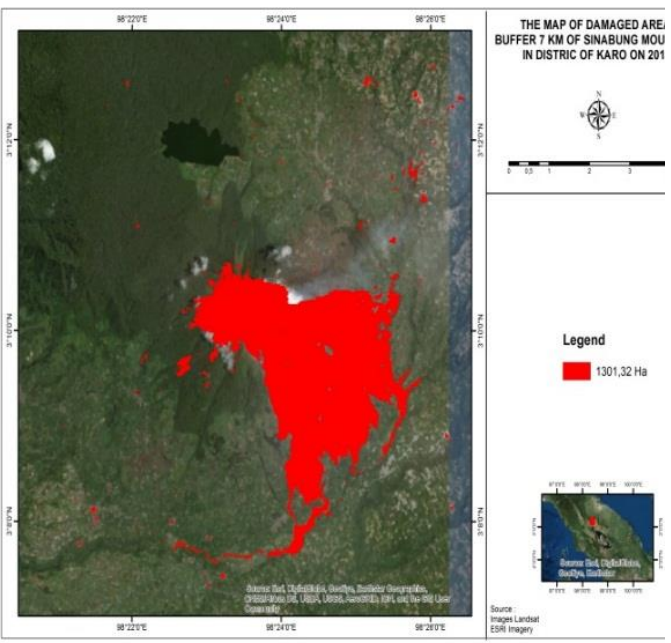

(d)

Fig 3: Risk assessment area at 5 km of Mt. Sinabung in (a). 2009; (b). 2014; (c) 2016; and (d) 2018. Erupted area shown in legend from dark green to the light red.

Based on the information, Mt. Sinabung was a favourite tourist attraction for tourists who like climbing. However, since the activities of Mount Sinabung again in 2010 up to now there have been many impacts from the eruption of the mountain. One of them is land damage caused by lava flows and volcanic ash bursts. From the calculation of NDVI and LST on Landsat 8 OLI imagery in 2009, 2014, 2016 and 2018, it provides an overview of the spreading area and the extent of damage in the $5 \mathrm{~km}$ due to Sinabung Mountain activities as shown in Figure 3.a, 3.d, 3 .c and 3.d below. From the figure above, it was concluded that land damage continued to increase every year due to Sinabung Mountain eruption as seen in 2014. It was very significant because the eruption in 2013, the impact was very large on the land damage around the mountain.

From the table below, it can be seen that the increase in land damage area and the most damaged was seen in 2014 due to the temperature above the surface which greatly affected the subsurface so that the extent of land damage in the area was seen. Table 3 below shows changes in land damage every year. From the table it can be stated that a decrease in NDVI values proves that land damage has increased

Table 3. Risk assessment area from Landsat 8 OLI from 2009 to 2018

\begin{tabular}{lll}
\hline No. & Year & NDVI Value \\
\hline 1 & 2009 & $\mathbf{1 2 0 . 7 3}$ \\
2 & $\mathbf{2 0 1 4}$ & $\mathbf{2 4 9 2 . 1 2}$ \\
3 & $\mathbf{2 0 1 6}$ & $\mathbf{1 2 5 6 . 4 0}$ \\
4 & $\mathbf{2 0 1 8}$ & $\mathbf{1 3 0 1 . 3 2}$
\end{tabular}




\subsection{Discussion}

Based on the image map 1.a, 1.b, 1.c, and 1.d, the NDVI map shows a decrease in the greenish level around Mt. Sinabung, and the value of the image in Figure 2.a, 2.b, 2.c and 2.d looks increasingly increased and it can be said that in the area of Mt. Sinabung had dramatically environmental changes. For land damage can be seen in Figure 3.a, 3.b, 3.c and 3.d, they stated that there has been an environmental change or land damage. All pictures and tables, it is proven that land damage has occurred which allows humans to not be able to live and grow crops in the area, It means that all residents living around $5 \mathrm{~km}$ from the top of Sinabung Mountain must be evacuated or mitigated.

\section{Conclusions}

When the NDVI decline is very drastic and the temperature increases, it can be concluded that environmental changes occur at these locations in the degraded landcategory. Because of land damage, there is population displacement or mitigation and for agricultural land, it must be 5 $\mathrm{km}$ from the top of Mt. Sinabung.

\section{References}

[1] Febrianty,H.: Dampak erupsi gunung Sinabung terhadap pendapatan sektor pariwisata di Kabupaten Karo. USU Press, North Sumatera.(2017)

[2]Safitri, A.E.: Simulasi Monitoring Emisi Gas So2 sebagai Indikator Bahaya Letusan Gunung Api Untuk Melatihkan Tindakan Evakuasi. Physics Journal,pp. 21-29.(2014)

[3]Howard, J. A.:.Penginderaan Jauh untuk Sumber Daya Hutan: Teori dan Aplikasi. GadjahMada University Press, Yogyakarta(1996)

[4]Lillesand, T.M.: F.W. Kiefer.: Penginderaan Jauh dan Interpretasi Citra.Gadjah Mada University Press, Yogyakarta (1979)

[5]ESRI.:ArcGIS Spatial Analyst, Advanced GIS Spatial Analysis Using Raster and Vector Data, ESRI Press, USA (2001)

[6]Prasetyo, A.: Modul Dasar Sistem Informasi Geografis. Multimedia press (2011)

[7]Mulyanta, E.S.: Pengolahan Digital Image dengan Photoshop CS2.Andi Publisher, Yogyakarta(2006)

[8]Thoha, A.S.: Sejarah Gunung Sinabung. USU Press, North Sumatra (2008)

[9]Sutawidjaja, I.S.: The August 2010 phreatic eruption of Mt. Sinabung. North Sumatera, Indonesian Journal of Geology.pp. 55.( 2013) 